\title{
Cost-effectiveness and Budget Impact of Routine Use of Fractional Exhaled Nitric Oxide Monitoring for the Management of Adult Asthma Patients in Spain
}

\author{
Sabatelli L', Seppälä U², Sastre J3', Crater G ${ }^{4}$
}

\author{
${ }^{1}$ GLOBMOD Health, Barcelona, Spain \\ ${ }^{2}$ Medical Affairs, Aerocrine AB, Solna, Sweden \\ ${ }^{3}$ Hospital Universitario Fundación Jiménez Díaz, Madrid, Spain \\ ${ }^{4}$ Global Clinical Development \& Medical Affairs, Morrisville, North Carolina, USA
}

J Investig Allergol Clin Immunol 2017; Vol. 27(2): 89-97

doi: 10.18176/jiaci.0103

\begin{abstract}
Objectives: Fractional exhaled nitric oxide (FeNO) is a marker for type 2 airway inflammation. The objective of this study was to evaluate the cost-effectiveness and budget impact of FeNO monitoring for management of adult asthma in Spain.

Methods: A cost-effectiveness analysis model was used to evaluate the effect on costs of adding FeNO monitoring to asthma management. Over a 1-year period, the model estimated the incremental cost per quality-adjusted life year and incremental number of exacerbations avoided when FeNO monitoring was added to standard guideline-driven asthma care compared with standard care alone. Univariate and multivariate sensitivity analyses were applied to explore uncertainty in the model. A budget impact model was used to examine the impact of FeNO monitoring on primary care costs across the Spanish health system.

Results: The results showed that adding FeNO to standard asthma care saved $€ 62.53$ per patient-year in the adult population and improved quality-adjusted life years by 0.026 per patient-year. The budget impact analysis revealed a potential net yearly saving of $€ 129$ million if FeNO monitoring had been used in primary care settings in Spain.

Conclusions: The present economic model shows that adding FeNO to the treatment algorithm can considerably reduce costs and improve quality of life when used to manage asthma in combination with current treatment guidelines.

Key words: Asthma management. Biomarker. Budget impact. Cost-effectiveness. FeNO. Guidelines. Exhaled nitric oxide.
\end{abstract}

\section{Resumen}

Objetivos: La fracción exhalada del óxido nítrico (FeNO) es un marcador de la inflamación bronquial de tipo Th-2. El objetivo de este estudio ha sido evaluar el coste-efectividad e impacto presupuestario de la monitorización del FeNO en el manejo del asma del adulto en España. Métodos: Se ha utilizado un modelo de análisis de coste-efectividad para evaluar los resultados económicos cuando se utilizó el FeNO en el manejo del asma durante un año. El modelo estimó el incremento de coste por calidad de vida ajustada por año (QALY) y el número de exacerbaciones evitadas cuando se añadió el FeNO a la guía habitual de tratamiento del asma en comparación con la guía habitual. Se aplicó un análisis univariante y multivariante para valorar la posible incertidumbre del modelo. Se utilizó un modelo de impacto presupuestario para evaluar el impacto económico de la introducción de la monitorización con el FeNO en consultas de atención primaria del estado español y teniendo en cuenta el sistema sanitario español.

Resultados: Se ha demostrado que el añadir el FeNO al tratamiento habitual del asma ahorra 62,53€ por paciente por año en adultos con asma y mejoró la QALYs en 0,026 por paciente y año. El análisis económico resultó en un ahorro estimado de 129 millones de euros netos por año en consultas de atención primaria.

Conclusiones: El modelo económico utilizado ha mostrado que el añadir el FeNO al algoritmo habitual de tratamiento del asma conlleva a un importante ahorro en recursos económicos y un aumento de la calidad de vida.

Palabras clave: Manejo de asma. Biomarcador. Impacto presupuestario. Coste-eficacia. Guías. Óxido nítrico exhalado. 


\section{Introduction}

Asthma is a chronic inflammatory disorder of the airways that carries a significant burden for many patients [1]. Worldwide, more than 300 million people of all ages and ethnic backgrounds have asthma, and it is estimated that by 2025 an additional 100 million people will be affected [2]. In Spain alone, the estimated prevalence of asthma is between $4 \%$ and $6 \%$ (ie, more than 2.3 million people) [3]. The prevalence of asthma among Spanish children aged 6 to 7 years is $6.2 \%$, which rises to $11 \%$ by age 14 [4]. This high and increasing prevalence of asthma has relevant cost implications for society in the form of increased medication use and hospitalizations, as well as loss of workdays and productivity [5]. Given the increasing prevalence of asthma and the relationship between cost and disease severity, effective management will be crucial in improving clinical and economic outcomes.

Fractional exhaled nitric oxide (FeNO) is a useful and reproducible surrogate marker for type 2 airway inflammation [6]. FeNO testing has shown its value in identifying individuals who respond to inhaled corticosteroids [7-8] and biologic therapy [9] and has acted as a complement to conventional monitoring of asthma in children and adults in several randomized controlled clinical trials [10-16]. Moreover, in 2014, the National Institute for Health and Care Excellence (NICE) recommended FeNO testing to help diagnose asthma in adults and children when diagnosis is unclear. FeNO testing is also recommended to help manage asthma in people who have symptoms despite using inhaled corticosteroids [17]. Improvements in both diagnosis and management algorithms will enable correct diagnosis and treatment of asthma, thus reducing exacerbations and unnecessary prescription of medications.

Economic evaluations of management strategies are an important component of decision-making when choosing the best approaches to asthma care [18]. Honkoop et al
[19] assessed the cost- and clinical effectiveness of asthma management algorithms by comparing outcomes between partially controlled asthma, controlled asthma, and FeNOdriven controlled asthma strategies. The authors found that a treatment strategy based on symptoms and FeNO testing reduced asthma medication use while sustaining asthma control and quality of life and resulted in the highest probability of cost-effectiveness for patients in primary care [19]. In costeffectiveness analyses performed in Germany and in the UK, FeNO measurements resulted in similar health benefits and savings when applied for asthma management $[18,20]$. Similarly, the objective of the present study was to compare the cost effectiveness of FeNO-assisted asthma management with that of standard guideline-driven care for management of asthma in Spain from the perspective of the Spanish health care system.

\section{Methods}

\section{Economic Model}

A decision tree model was built to estimate the impact of FeNO testing on asthma management costs and health outcomes (Figure 1). The outcomes associated with monitoring asthma in primary care settings using FeNO testing in addition to standard guideline-based care were compared with standard guideline-directed care alone [18]. The use and cost of each strategy and associated outcomes were identified after conducting a structured literature search in MEDLINE using the following criteria: asthma AND cost AND Spain, asthma AND management AND clinical AND Spain, asthma AND effectiveness AND clinical AND Spain, asthma AND management AND cost AND effectiveness AND SPAIN, asthma AND NO AND effectiveness AND cost-effectiveness, asthma AND FeNO AND effectiveness AND cost-effectiveness, and asthma NOT COPD AND nitric AND oxide AND fractional

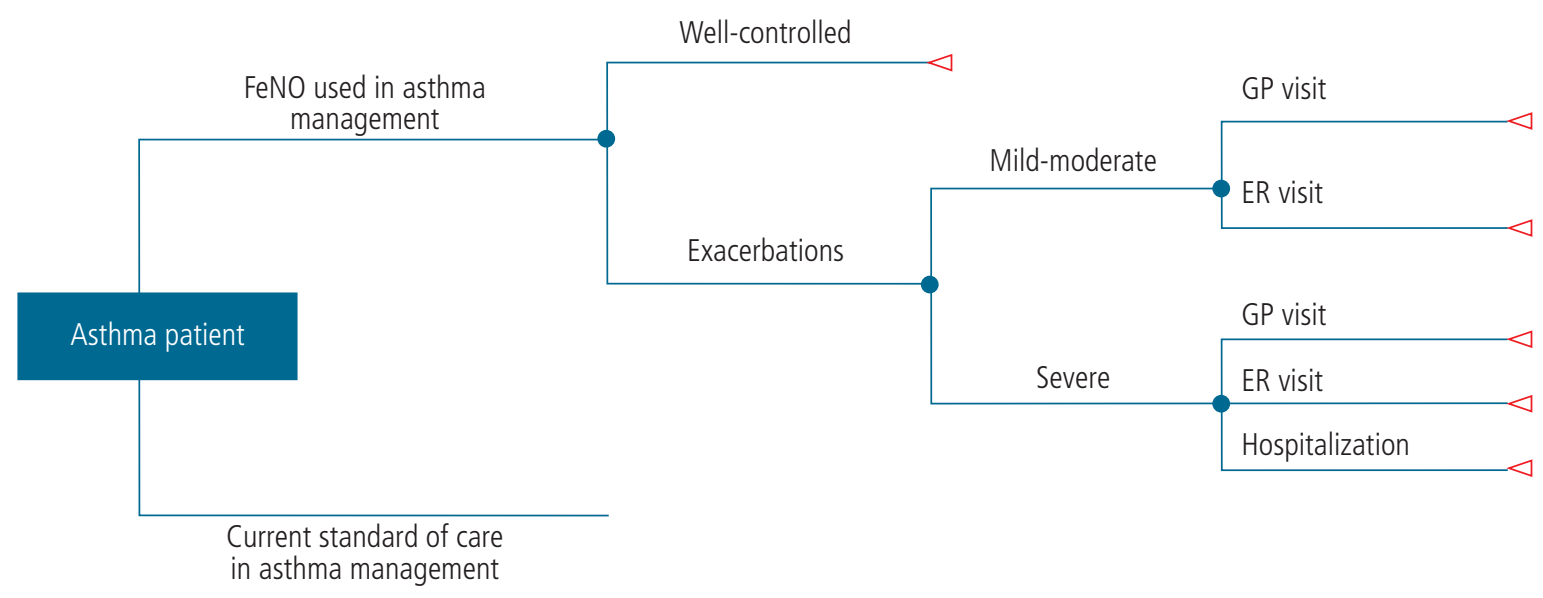

Figure 1. Asthma management decision tree. The decision tree represents the results for different outcomes after management of asthma with FeNO compared with guideline-driven standard care. The key outcomes in asthma management are successful control and exacerbations; these are related to GP visits, ER visits, and hospitalizations. The outcomes experienced under guideline-driven standard care are qualitatively identical to the outcomes experienced by patients that are managed with FeNO monitoring in addition to standard care (therefore the lower branch of the tree is not shown). ER, indicates emergency room; FeNO, fractional exhaled nitric oxide; GP, general practitioner. 
Table 1. Baseline and Effectiveness Parameters

\begin{tabular}{|c|c|c|}
\hline Baseline & $\begin{array}{l}\text { Base-Case Value } \\
\text { (Range for Univariate } \\
\text { Sensitivity Analysis) }\end{array}$ & Source \\
\hline Adult Spanish population & 39717627 & $\begin{array}{l}\text { INE (Spanish National Institute of Statistics, } \\
\text { www.ine.es }\end{array}$ \\
\hline Adult prevalence of asthma (minimum) & $2 \%$ & Spanish Guidelines for Asthma Management [1] \\
\hline $\begin{array}{l}\text { Likelihood of exacerbations when using } \\
\text { standard guidelines }\end{array}$ & $0.52(0.26-0.78)$ & Akinbami et al [33] \\
\hline Likelihood that exacerbations are moderate-severe & $0.23(0.12-0.35)$ & Jayaram et al, 2006 [34] \\
\hline $\begin{array}{l}\text { Likelihood that mild-moderate asthma } \\
\text { exacerbations will be treated at an emergency } \\
\text { room or urgent care center }\end{array}$ & $0.08(0.04-0.12)$ & $\begin{array}{l}\text { Borderias-Clau et al, } 2005 \text { [22] } \\
\text { Martinez-Moragon et al, } 2009 \text { [23] }\end{array}$ \\
\hline $\begin{array}{l}\text { Likelihood that a standard care patient } \\
\text { experiencing a moderate-severe } \\
\text { exacerbation will require hospitalization }\end{array}$ & $0.34(0.17-0.51)$ & $\begin{array}{l}\text { Calculation based on: } \\
\text { Borderias-Clau et al, } 2005 \text { [22] } \\
\text { Martinez-Moragon et al, } 2009 \text { [23] }\end{array}$ \\
\hline $\begin{array}{l}\text { Likelihood that mild-moderate asthma } \\
\text { exacerbations will be treated at an } \\
\text { emergency room or urgent care center }\end{array}$ & $0.18(0.09-0.27)$ & $\begin{array}{l}\text { Borderias-Clau et al, } 2005 \text { [22] } \\
\text { Martinez-Moragon et al, } 2009 \text { [23] }\end{array}$ \\
\hline \multicolumn{3}{|l|}{ Effectiveness } \\
\hline Reduction in ICS dose due to FeNO use & $0.20(-0.05$ to 0.45$)$ & Donohue and Jain, 2013 [8] \\
\hline $\begin{array}{l}\text { Reduction in risk of exacerbations due to } \\
\text { FeNO use }\end{array}$ & $0.23(0.00-0.46)$ & $\begin{array}{l}\text { Syk et al, } 2013[15] \\
\text { Smith et al, } 2005[10] \\
\text { Shaw et al, } 2007[11]\end{array}$ \\
\hline
\end{tabular}

AND exhaled AND management. Additional manual searches were also performed using PubMed. Results were limited to English and Spanish language publications of clinical studies published between January 2000 and December 2013. An additional manual search of PubMed was conducted to the end of 2015 . In total, 157 papers were identified and individually screened. The information obtained through the literature search was used in the cost-effectiveness model (implemented in Microsoft Excel). The evidence was based on outcomes collected in the first year of use. It was assumed that the use of FeNO monitoring would be unlikely to produce long-term outcomes at variance with those observed in the first year. In the model, we assumed 2 FeNO measurements per year. No discount rate was applied. Costs refer to the year 2012. When no data were available for a specific year, costs from previous years were projected into the future using a discount rate of $3.5 \%$. The parameters used in the asthma management model are summarized in Table 1.

\section{Study Population and Outcomes}

In the base case, the cohort comprised 100000 asthma patients resident in Spain aged $\geq 15$ years. Based on data from the Spanish National Institute of Statistics, the total adult Spanish population enrolled in the Spanish National Health System was estimated to be just under 40 million (39 717 627) in 2015 (www.ine.es). The primary outcomes assessed the economic model were as follows:

(a) Total cost of managing 1 asthma patient for 1 year (b) Total health benefits (eg, quality-adjusted life years [QALYs]) per patient accrued over 1 year

The model also generated the following secondary outcomes:

(a) Reduction in hospitalizations due to asthma exacerbation

(b) Reduction in emergency room (ER) visits due to asthma exacerbation

(c) Reduction in general practitioner (GP) visits due to asthma exacerbation

(d) Change in the average cost of 1 asthma patient attributable to hospitalizations

(e) Change in the average cost of 1 asthma patient attributable to ER visits

(f) Change in the average cost of 1 asthma patient attributable to GP visits

\section{Effectiveness Analysis}

The effectiveness parameters of FeNO monitoring were estimated using 3 prospective randomized controlled trials. Two of these studies $[10,11]$ had been included in systematic reviews of asthma treatment and FeNO monitoring [7,8]; the third study [15] was a FeNO-driven randomized controlled trial of anti-inflammatory treatment of atopic asthma. A study by Powell et al [16] conducted on a population of pregnant women was not used because its outcomes may have been influenced by pregnancy [16]. A random-effect meta-analysis of the 3 eligible studies was performed to summarize their 
results. The meta-analysis was based on the model of Dersimonian and Laird [21] and was implemented using the $\mathrm{R}$ package 'metafor'. The analysis found a -0.23 (95\%CI, -0.36 to -0.09$)$ difference between the exacerbation rates observed in the FeNO monitoring arm and in the control arm. The results were subsequently adjusted to account for the prevalence of smoking in Spain (Spanish National Institute of Statistics, www.ine.es) under the assumption that FeNO monitoring might not improve outcomes in patients who are tobacco smokers [8]. An average exacerbation rate of 0.78 personyears was calculated by multiplying the average number of exacerbations per year in poorly controlled asthmatic patients by the probability for an asthmatic patient of being poorly controlled using parameters derived from expert opinion and from data reported by Borderias-Clau et al [22] and MartinezMoragon et al [23]. The estimated average reduction in the rate of exacerbations was $22.7 \%$.

The evidence on the usage of inhaled corticosteroids (ICS) is based on a systematic review [8] that found an approximately $27 \%$ average reduction in use of ICS when FeNO monitoring was applied in adult patients. This estimate was then adjusted to account for the prevalence of smoking in Spain. The parameter value used in the model was $20 \%$.

Health-related quality of life inputs (utilities) were applied to each health state in order to generate QALYs. Utilities were derived from the study by Szende et al [24].

The economic evaluations were conducted from a Spanish health care payer perspective. Drug costs were calculated using public prices and prices of generic products, from average dosages across recommended dose ranges for conventional maintenance and rescue therapies for asthma (Spanish Pharmacists Association, www.cofm.es) using sources from the pharmaceutical industry (https://botplusweb.portalfarma. com/). The costs of hospitalization, visits to the ER, and primary care medical visits were estimated by averaging the results from the studies by Gonzalez-Barcala et al $[25,26]$ and publicly available statistics on the cost of health care (eg, from the Catalan Department of Health) [27]. The cost of a hospitalization episode was calculated based on an average stay of 6 days (average stays in the literature range between 6 and 9.2 days for asthmatic patients hospitalized in the Spanish health system), and an average daily cost of $€ 420$ (€300-€600, depending on hospital and length of stay). The cost of FeNO monitoring is based on the figures provided by Aerocrine AB, the manufacturer of NIOX MINO, a FeNO monitoring device.

The incremental cost-effectiveness ratio (ICER) was calculated using the following formula:

Cost FeNO - Cost current practice

QALYs lost FeNO - QALYs lost current practice

\section{Sensitivity Analysis}

A 1-way sensitivity analysis was performed to explore uncertainty in individual parameters in the ICER. A probabilistic sensitivity analysis was performed to assess the robustness of the ICER to simultaneous changes in parameters. Probability distributions were fitted to key model parameters. Uniform distributions were applied in most cases to account
Table 2. Results of Base Case Analysis

\begin{tabular}{lccc}
\hline & $\begin{array}{c}\text { FeNO Monitoring } \\
\text { in Addition to } \\
\text { Standard Asthma } \\
\text { Management } \\
\text { Guidelines }\end{array}$ & $\begin{array}{c}\text { Standard } \\
\text { Asthma } \\
\text { Management } \\
\text { Guidelines } \\
\text { Alone }\end{array}$ & Increment \\
\hline Total cost/patient & $€ 790.05$ & $€ 852,58$ & $-€ 62.53$ \\
QALYs/patient & 0.802 & 0.776 & 0.026 \\
ICER ( $€$ per QALY) & & & Dominant
\end{tabular}

Abbreviations: FeNO, fractional exhaled nitric oxide; ICER, incremental cost-effectiveness ratio; QALY, quality-adjusted life year.

for potential sources of uncertainty not captured by the specific confidence intervals of individual parameters. Beta distributions were used for utility parameters. Distributions were chosen based on data from the literature or on plausible assumptions and expert opinions when no clear evidence was available. The ICERs obtained from 1000 iterations and stochastically sampled from the distributions were used to estimate a mean value.

\section{Results}

\section{Base Case Analysis}

Adding FeNO testing to standard guideline-directed care resulted in savings of $€ 62.53$ per patient-year compared with standard guideline-directed care alone (Table 2). The associated health gain was estimated at 0.026 QALYs per person-year. Adopting FeNO monitoring in routine asthma management improved standard guideline-directed care, was more effective, and generated cost savings. Improved QALYs and cost savings were established owing to the reduced number of exacerbations and reduced prescription and consumption of ICS. The number of averted hospitalizations, emergency room visits, and urgent primary care visits per 100000 adult asthma patients monitored using FeNO was 923, 1,216, and 9,665 respectively (Figure 2). The savings per patient due to averted hospitalizations, ER visits, and urgent primary care visits were $€ 41.58, € 10.98$, and $€ 73.91$, respectively (Figure 3).

\section{One-Way Sensitivity Analysis}

The 1-way sensitivity analysis (Table 3 ) showed that FeNO-assisted asthma management was dominant for all parameter changes. Savings per patient were most sensitive to effectiveness parameters, cost of hospitalization, and likelihood of experiencing and severity of exacerbations.

\section{Probabilistic Sensitivity Analysis}

The ICER resulting from each probabilistic sensitivity analysis iteration is shown in Figure 4. Points lying to the right of the frontier represent cost-effective ICERs at the conventional cost/QALY threshold of $€ 30000$, thus showing that applying FeNO testing to standard guideline-directed care is more cost-effective than following standard guideline- 

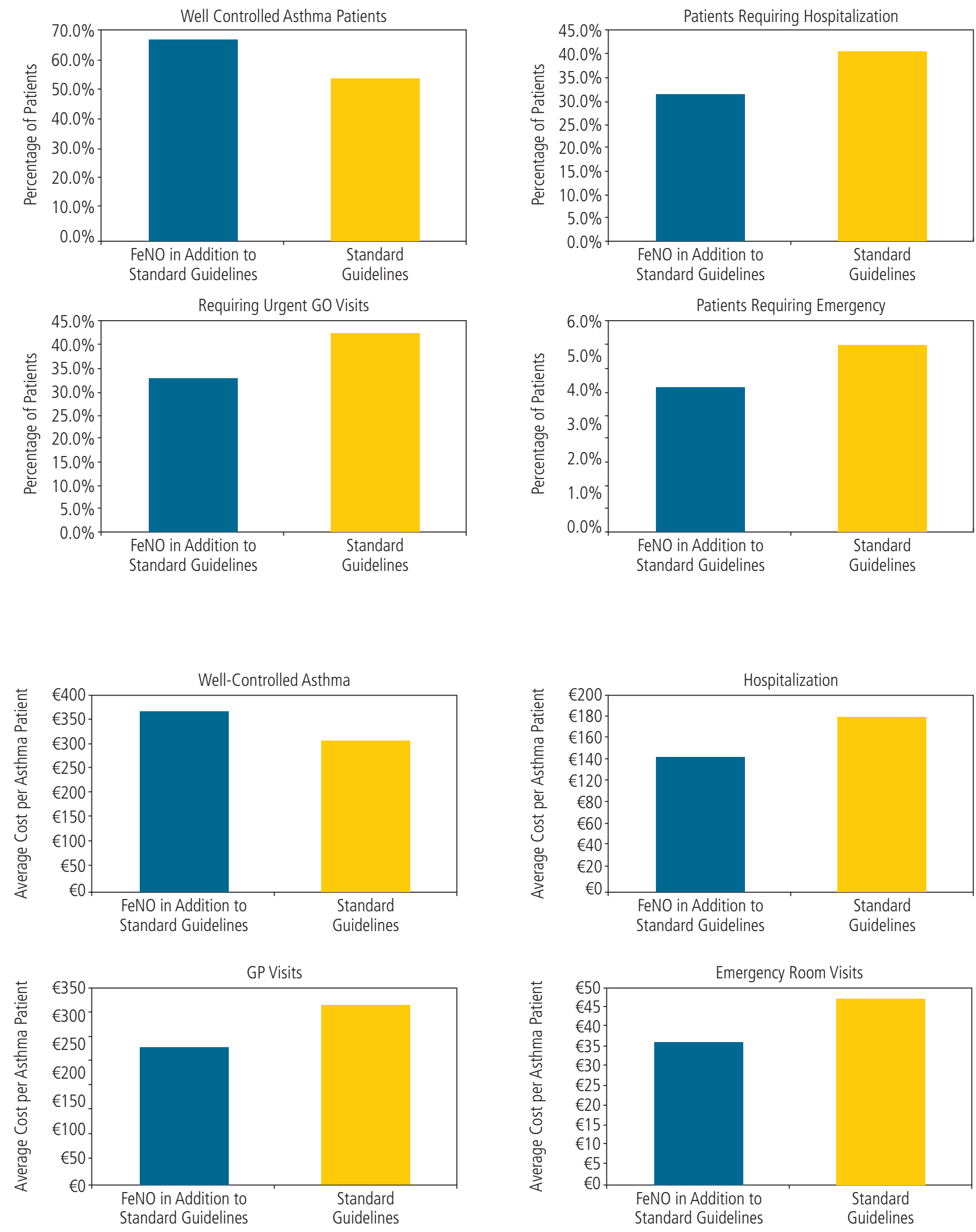

Figure 3. Comparison of cost outcomes in adult asthma patients managed with FeNO plus standard care vs standard guideline-driven care alone. FeNO indicates fractional exaled nitric oxide; GP, general practitioner. 
Table 3. Cost and Resource Use Parameters

\begin{tabular}{|c|c|c|}
\hline & $\begin{array}{l}\text { Base-Case Value } \\
\text { (Range for Univariate } \\
\text { Sensitivity Analysis) }\end{array}$ & Source \\
\hline Cost of FeNO & $€ 9.00(4.50-13.50)$ & Aerocrine (manufacturer of NIOX MINO) \\
\hline Cost of spirometry & $€ 1.50(0.75-2.25)$ & $\begin{array}{l}\text { Assumption based on Price et al [18], adjusted for the Spanish } \\
\text { market }\end{array}$ \\
\hline $\begin{array}{l}\text { Annual Spanish national health } \\
\text { system cost for inhaled corticosteroids } \\
\text { (prescribing based on standard } \\
\text { guidelines) }\end{array}$ & $€ 189.00(94.50-283.50)$ & $\begin{array}{l}\text { Spanish Pharmacists Association, } \\
\text { https://botplusweb.portalfarma.com/ } \\
\text { Pharma industry sources, Madrid COdFd. } \\
\text { http://www.cofm.es (2013) }\end{array}$ \\
\hline $\begin{array}{l}\text { Annual Spanish national health } \\
\text { service cost for long-acting } \beta \text {-agonists } \\
\text { (prescribing based on standard } \\
\text { guidelines) }\end{array}$ & $€ 372.80(186.40-559.20)$ & $\begin{array}{l}\text { Spanish Pharmacists Association, } \\
\text { https://botplusweb.portalfarma.com// } \\
\text { Pharma industry sources, Madrid COdFd. } \\
\text { http://www.cofm.es (2013) }\end{array}$ \\
\hline $\begin{array}{l}\text { Cost of rescue medications for } \\
\text { moderate-severe exacerbations }\end{array}$ & $€ 7.00(3.50-10.50)$ & $\begin{array}{l}\text { Spanish Pharmacists Association, } \\
\text { https://botplusweb.portalfarma.com/ } \\
\text { Pharma industry sources, Madrid COdFd. } \\
\text { http://www.cofm.es (2013) }\end{array}$ \\
\hline $\begin{array}{l}\text { Cost of rescue medications for } \\
\text { mild-moderate exacerbations }\end{array}$ & $€ 2.14(1.07-3.21)$ & $\begin{array}{l}\text { Spanish Pharmacists Association, } \\
\text { https://botplusweb.portalfarma.com/ } \\
\text { Pharma industry sources, Madrid COdFd. } \\
\text { http://www.cofm.es (2013) }\end{array}$ \\
\hline $\begin{array}{l}\text { Cost per office visit to general } \\
\text { practitioner }\end{array}$ & $€ 40(20-60)$ & $\begin{array}{l}\text { Based on figures reported in Gonzalez-Barcala et al }[25,26] \\
\text { and by the Catalan Department of Health }[31]\end{array}$ \\
\hline $\begin{array}{l}\text { Spanish NHS cost per GP visit for } \\
\text { asthma exacerbation }\end{array}$ & $€ 60(30-90)$ & $\begin{array}{l}\text { Based on figures from official documents of the Catalan } \\
\text { Department of Health and from Gonzalez-Barcala et al }[25,26]\end{array}$ \\
\hline $\begin{array}{l}\text { Cost of visit to ER for asthma } \\
\text { exacerbation }\end{array}$ & $€ 151(75.50-226.50)$ & $\begin{array}{l}\text { Based on figures from official documents of the Catalan } \\
\text { Department of Health [27] and from Gonzalez-Barcala et al }[25,26]\end{array}$ \\
\hline $\begin{array}{l}\text { Average hospital cost for admission } \\
\text { due to asthma exacerbation }\end{array}$ & $€ 2520(1260-3780)$ & $\begin{array}{l}\text { Based on figures from official documents of the Catalan } \\
\text { Department of Health [27] and from Gonzalez-Barcala et al }[25,26]\end{array}$ \\
\hline $\begin{array}{l}\text { Annual number of check-ups } \\
\text { for asthma management }\end{array}$ & $2.00(1.00-3.00)$ & Martinez-Moragon et al, 2009 [23] \\
\hline $\begin{array}{l}\text { Average annual number of exacerbations } \\
\text { in non well-controlled patients }\end{array}$ & $1.50(0.75-2.25)$ & Based on clinical expert opinion (Professor Sastre) \\
\hline
\end{tabular}

Abbreviations: ER, emergency room; FeNO, fractional exhaled nitric oxide; NHS, National Health System.

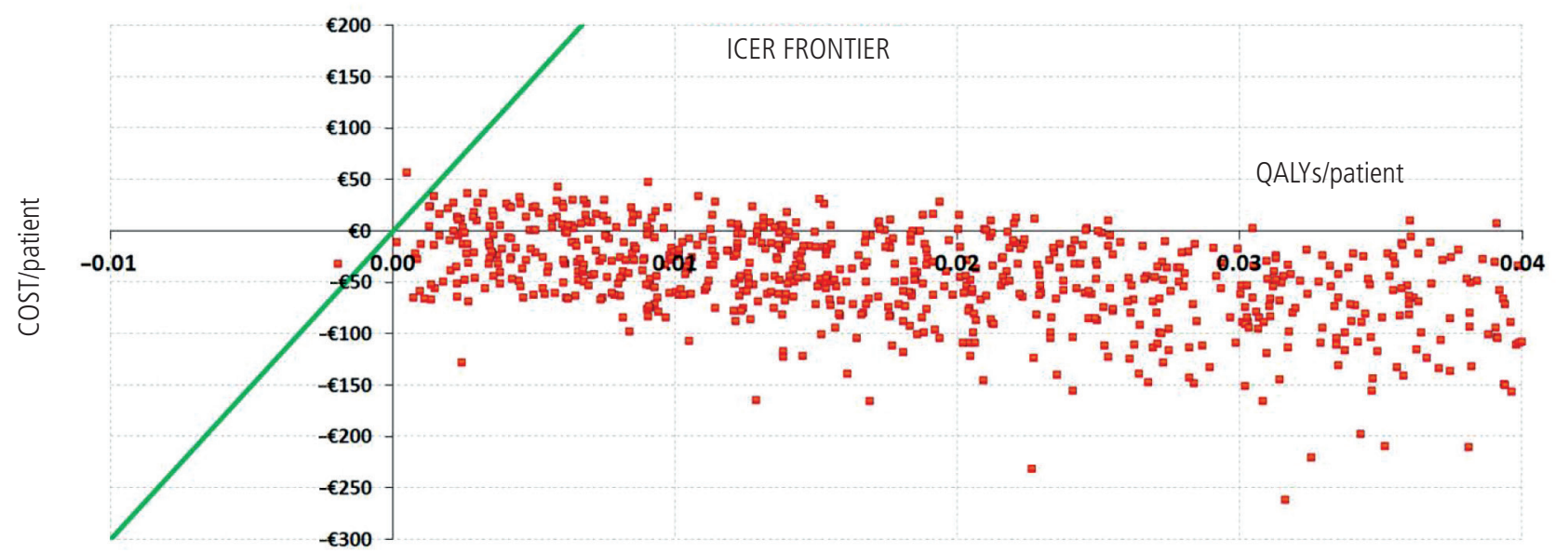

Figure 4. Multivariate probabilistic sensitivity analysis of cost and health incremental outcomes associated with fractional exhaled nitric monitoring plus standard care vs standard guideline-driven care alone. Each point corresponds to a unique set of stochastically selected parameter values, obtained using a Monte Carlo simulation. The green line defines a cost-effectiveness threshold equal to $€ 30000$. QALY, indicates quality adjusted life year. 
Table 4. Budget Impact of FeNO Monitoring in Spain for Varying Uptake Rates (Approximated to the Closest €1000) and a Prevalence of 5.2\%

\begin{tabular}{lcccc}
\hline Uptake Scenario & $20 \%$ & $40 \%$ & $80 \%$ & $100 \%$ \\
\hline $\begin{array}{l}\text { Upfront } \\
\text { investment, } €\end{array}$ & 9501000 & 19002000 & 38005000 & 47506000 \\
Net savings, $€$ & 25829000 & 51659000 & 103317000 & 129147000
\end{tabular}

directed care alone in over $99 \%$ of cases (998/1000 simulation runs) and generates cost savings (dominant) in more than $87 \%$ of cases (874/1000 simulation runs).

\section{Budget Impact Analysis}

Budget impact was calculated considering 4 scenarios. Scenario 1 assumed a maximum uptake of FeNO monitoring in $20 \%$ of all medical facilities, rising to $40 \%$ in scenario 2 , $80 \%$ in scenario 3 , and $100 \%$ in scenario 4 . For each scenario, net savings were calculated by summing savings from adverse events avoided and reduced drug use and deducting the cost of devices. The results of the budget impact analysis (Table 4) were affected by the assumed likelihood of exacerbation, effectiveness parameters, cost of ICS, medical visits, and hospitalizations. The savings associated with use of FeNO monitoring in primary care settings outweigh the purchase cost. For instance, if $40 \%$ of primary care centers in Spain adopted FeNO monitoring, the total net savings to the Spanish health system would be over $€ 51$ million.

\section{Discussion}

Traditional asthma management is based on pharmacological strategies that are outlined in global and national asthma guidelines [1, http://www.ginasthma.org]. The cost-effectiveness and cost-utility of pharmacological strategies have been rigorously assessed [29]. However, until recently, the utility of biomarker-assisted asthma diagnosis and management has received little attention $[1,6,9]$. In airway diseases, biomarkers such as FeNO and blood and sputum eosinophils have been used to provide predictive information to tailor treatments and to differentiate between patients with similar clinical presentations [6,28,29].

Across Europe, health care is provided through a wide range of national systems; therefore, country-specific data are needed to identify potential ways to reduce health care costs. Recently, standard guideline-based studies in primary care settings in France and Spain evaluated the association between asthma control, health care costs, and quality of life. In Spain, the average cost (euros/3 months/patient) of controlled asthma was $€ 152$.60, increasing steadily to $€ 241.20$ and $€ 556.80$ in partly controlled and uncontrolled patients. Asthma medication was the main driver of the direct costs for controlled and partly controlled disease, whereas costs associated with hospitalizations for asthma and emergency room visits were higher in uncontrolled asthma patients [30]. In the present study, the cost-effectiveness analysis showed that adding FeNO testing to standard guideline care resulted in savings of $€ 62.53$ per patient-year compared with standard guideline-directed care alone (Table 3). Savings per patient were most sensitive to effectiveness parameters, cost of hospitalization, and likelihood and severity of exacerbations (Figures 2 and 3).

Management and prevention of asthma exacerbations is a key focus of asthma care [31]. Reduced exacerbation rates and improved symptom control without increasing overall use of ICS were recently demonstrated when a FeNO-guided anti-inflammatory treatment algorithm was assessed and compared with standard care [15]. In addition, in patients with refractory asthma, FeNO testing has been shown to correlate with adherence to anti-inflammatory treatment, indicating that a simple, noninvasive point-of-care test can make a difference in clinical practice and improve disease management and health outcomes [14,29].

In the present study, the budget impact analysis showed steadily increasing yearly net savings of approximately $€ 129$ million if FeNO-driven asthma management had been used in Spanish primary care settings (Table 4). Similarly, in a recent Dutch primary care study, the total societal costs were lowest for the FeNO-driven strategy, including lower costs for asthma medications [19]. As a result, the FeNO-driven management strategy had a more than $86 \%$ chance of being the most costeffective strategy for a willingness to pay of $\geq \$ 50000$ per QALY. Similarly, our ICER analysis showed that combining FeNO testing with standard guideline care was cost-effective compared with standard guideline-directed care alone in over $99 \%$ of cases and generated cost-savings in more than $87 \%$ of cases (Figure 4).

In line with the recent meta-analysis of the effects of FeNOguided asthma management on major/severe exacerbation rates by Harnan et al [32], our meta-analysis (Figure 5) showed a $-0.23(95 \% \mathrm{CI},-0.36$ to -0.09$)$ difference between the exacerbation rates observed in the FeNO monitoring arm and in the control arm in the general asthma population. In our analysis, the estimated average reduction in the rate of exacerbations was $22.7 \%$, leading to a modest impact for improved QALYs by 0.026 per patient-year.

A key strength of the present model is that the estimates are country-specific (Table 1) and have been shown to be

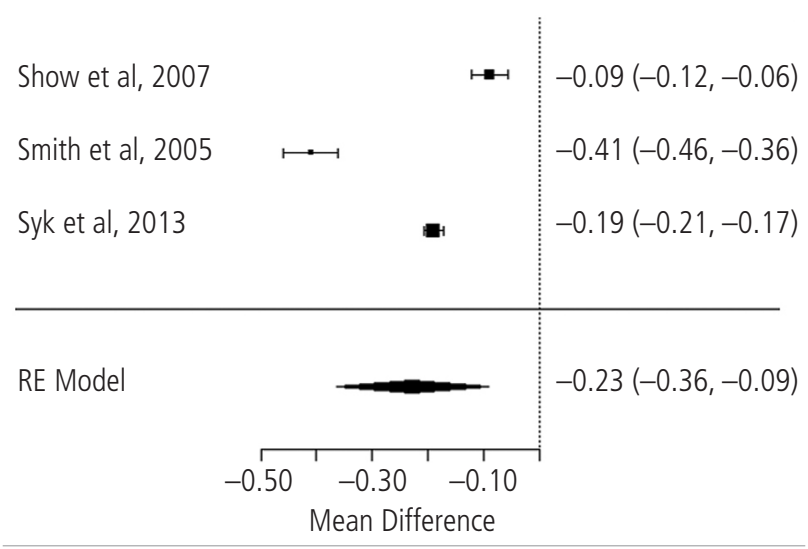

Figure 5. Results of the meta-analysis: reduction in exacerbation rates associated with fractional exhaled nitric oxide monitoring (random-effect [RE] model). 
key determinant of cost-effectiveness in previous studies in Germany and the UK $[18,20]$. However, our study is also affected by limitations such as the low number of clinical effectiveness studies, where reductions in exacerbation rates were the primary outcome. In addition, since the heterogeneity of the study populations, protocols, outcomes, and management guidelines in earlier studies led to poor outcomes, these studies could not be included in our model. The present analysis did not take into account high-risk subgroups with common comorbidities and patients with asthma-COPD overlap syndrome owing to the small number or lack of clinical studies in this area [32]. However, biomarker-based assessment of inflammation may have a role in diagnosis and personalization of treatment [28]. Therefore, future studies should assess which asthma management strategy can produce the best asthma outcomes and include long-term follow-up in diagnosis and management studies [32,35].

From the perspective of the Spanish health authorities, the main payers in the Spanish health system, the adoption of FeNO-assisted strategies for the management of adult asthmatic patients in primary care settings $[11,19]$ appears to be associated with a more cost-effective use of public resources.

\section{Funding}

These findings are the result of work supported by Aerocrine AB. The views expressed in this paper are those of the authors.

\section{Conflicts of Interest}

Dr Seppälä is employed by Circassia AB (formerly known as Aerocrine AB). Dr Crater was employed by Aerocrine Inc when the study was conducted. Dr Sabatelli is employed by GLOBMOD Health (GLOB MOD SL), which received consultation fees from Aerocrine $\mathrm{AB}$ when the study was conducted. Professor Joaquin Sastre is an Associate Editor of the Journal of Investigational Allergology and Clinical Immunology and received fees from Thermo Fisher when the study was conducted.

\section{Previous Presentations}

The study was presented as an abstract/poster entitled "Economic evaluation of fractional exhaled nitric oxide (FeNO) for the management of adult asthma in Spain" at the European Respiratory Society Congress, Amsterdam, 2015.

\section{References}

1. Plaza Moral V. GEMA4.0. Guidelines for Asthma Management. Arch Bronconeumol. 2015;51 Suppl 1:2-54.

2. Anandan C, Nurmatov U, van Schayck OC, Sheikh A. Is the prevalence of asthma declining? Systematic review of epidemiological studies. Allergy. 2010;65:152-67.

3. Quirce S. Asthma in Alergológica-2005. J Investig Allergol Clin Immunol. 2009;19 Suppl 2:14-20.

4. Domínguez-Ortega J, Phillips-Anglés E, Barranco P, Quirce S. Cost-effectiveness of asthma therapy: a comprehensive review. J Asthma. 2015;52:529-37.
5. Ojeda P, Sanz de Burgoa V. Costs Associated With Workdays Lost and Utilization of Health Care Resources Because of Asthma in Daily Clinical Practice in Spain. J Investig Allergol Clin Immunol. 2013;23:234-41.

6. Baines KJ, Pavord ID, Gibson PG. The role of biomarkers in the management of airways disease. Int J Tubercul Lung Dis. 2014;18:1264-8.

7. Smith $A D$, Cowan JO, Brassett KP, Filsell $S$, McLachlan $C$, Monti-Sheehan G, Herbison GP, Taylor DR. Exhaled Nitric Oxide: A Predictor of Steroid Response. Am J Respir Crit Care Med. 2005; 172:453-9.

8. Donohue JF, Jain N. Exhaled nitric oxide to predict corticosteroid responsiveness and reduce asthma exacerbation rates. Respir Med. 2013;107:943-52.

9. Hanania NA, Wenzel S, Rosén K, Hsieh H-J, Mosesova S, Choy DF, Lal P, Arron JR, Harris JM, Busse W. Exploring the Effects of Omalizumab in Allergic Asthma: An Analysis of Biomarkers in the EXTRA Study. Am J Respir Crit Care Med. 2013;187:80411.

10. Smith AD, Cowan JO, Brassett KP, Herbison GP, Taylor RD. Use of Exhaled Nitric Oxide Measurements to Guide Treatment in Chronic Asthma. N Engl J Med. 2005;352:2163-73.

11. Shaw DE, Berry MA, Thomas $T$, Green $R H$, Brightling $C E$, Wardlaw AJ, Pavord ID. The Use of Exhaled Nitric Oxide to Guide Asthma Management. A Randomized Controlled Trial. Am J Respir Crit Care Med. 2007;176:231-7.

12. Peirsman EJ, Carvelli TJ, Hage PY, Hanssens LS, Pattyn L, Raes MM, Sauer KA, Vermeulen F, Desager KN. Exhaled nitric oxide in childhood allergic asthma management a randomised controlled trial. Pediatr Pulmonol. 2014;49:624-31.

13. Petsky HL, Li AM, Au CT, Kynaston JA, Turner C, Chang AB. Management based on exhaled nitric oxide levels adjusted for atopy reduces asthma exacerbations in children: A dual centre randomized controlled trial. Pediatr Pulmonol. 2015;50:53543.

14. McNicholl DM, Stevenson M, McGarvey LP, Heaney LG. The utility of fractional exhaled nitric oxide suppression in the identification of nonadherence in difficult asthma. Am J Respir Crit Care Med. 2012;186:1102-8.

15. Syk J, Malinovschi A, Johansson $G$, Undén A-L, Andreasson A, Lekander M, Alving K. Anti-inflammatory Treatment of Atopic Asthma Guided by Exhaled Nitric Oxide: A Randomized, Controlled Trial. J Allergy Clin Immunol Pract. 2013;1:639-48. e8.

16. Powell H, Murphy VE, Taylor DR, Hensley MJ, McCaffery K, Giles W, Clifton VL, Gibson PG. Management of asthma in pregnancy guided by measurement of fraction of exhaled nitric oxide: a double-blind, randomised controlled trial. Lancet. 2011;378:983-90.

17. Asthma - diagnosis and monitoring. Guidance and guidelines NICE. Available at: http://www.nice.org.uk/guidance/ indevelopment/GID-CGWAVE0640

18. Price D, Berg J, Lindgren P. An economic evaluation of NIOX MINO airway inflammation monitor in the United Kingdom. Allergy. 2009:64:431-8.

19. Honkoop PJ, Loijmans RJB, Termeer EH, Snoeck-Stroband JB, van den Hout WB, Bakker MJ, Assendelft WJJ, ter Riet G, Sterk PJ, Schermer TRJ, Sont JK. Symptom- and fraction of exhaled nitric oxide-driven strategies for asthma control: A cluster- 
randomized trial in primary care. J Allergy Clin Immunol. 2015;135:682-8.e11.

20. Berg J, Lindgren P. Economic evaluation of FeNO measurement in diagnosis and 1-year management of asthma in Germany. Respiratory Medicine. 2008:102;219-31.

21. DerSimonian R, Laird N. Meta-analysis in clinical trials. Control Clin Trials. 1986;7(3):177-88.

22. Borderías Clau L, Zabaleta Murguionda M, Riesco Miranda JA, Pellicer Ciscar C, Hernández Hernández JR, Carrillo Díaz T, Lumbreras García G. Cost and management of asthma exacerbations in Spanish hospitals (COAX study in hospital services. Arch Bronconeumol. 2005;41:313-21.

23. Martínez-Moragón E, Serra-Batllés J, De Diego A, Palop M, Casan P, Rubio-Terrés C, Pellicerg C, on behalf of the AsmaCost Study Group. Economic cost of treating the patient with asthma in Spain: the AsmaCost study. Arch Bronconeumol. 2009;45:481-6.

24. Szende A, Leidy NK, Ståhl E, Svensson K. Estimating health utilities in patients with asthma and COPD: evidence on the performance of EQ-5D and SF-6D.Qual Life Res. 2009;18:26772.

25. González Barcala FJ, de la Fuente-Cid R, Álvarez-Gil R, Tafalla $M$, Nuevo J, Caamaño-Isorna F. Factores asociados con el control del asma en pacientes de atención primaria en España: el estudio CHAS. Arch Bronconeumol. 2010;46(07):358-63.

26. Gonzalez-Barcala F, Aboal J, Valdes L, Carreira J, AlvarezDobano J, Puga A, Garcia-Sanz MT, Takkouche B. Trends in adult asthma hospitalization: gender-age effect. Multidiscip Respir Med. 2011;6(2):82-6.

27. DEPARTAMENT-DE-SALUT. SLT/42/2012, de 24 de febrer, per la qual es regulen els supòsits i conceptes facturables i s'aproven els preus públics corresponents als serveis que presta I'Institut Català de la Salut. Diari Oicial de la Generalitat de Catalunya 2012;Núm. 6079 (2.3.2012).

28. Thomas M, Taylor RD. Assessing inflammatory phenotypes and improving the cost-effectiveness of asthma and COPD care in the community. Prim Care Respir J. 2011;20:349-50.

29. Brisk R, Heaney LG. Asthma control and exacerbations: two different sides of the same coin. Curr Opin Pulm Med. 2016:22:32-7.

30. Doz M, Chouaid C, Com-Ruelle L, Calvo E, Brosa M, Robert J, Decuypère, Pribil C, Huerta A, Detournay B. The association between asthma control, health care costs, and quality of life in France and Spain. BMC Pulm Med. 2013;13:15.

31. Fuhlbrigge $A$, Peden $D$, J. Apter $A$, Boushey $H A$, Camargo $C A$, Gern J, Heymann PW, Martinez FD, Mauger D, Teague WG, Blaisdell C. Asthma outcomes: Exacerbations. J Allergy Clin Immunol. 2012;129:S34-48.

32. Harnan SE, Tappenden P, Essat M, Gomersall T, Minton J, Wong R, Pavord I, Everard M, Lawson R. Measurement of exhaled nitric oxide concentration in asthma: a systematic review and economic evaluation of NIOX MINO, NIOX VERO and NO breath. Health Technol Assess. 2015 Oct;19(82):1-330.

33. Akinbami LJ, Moorman JE, Bailey C, Zahran HS, King $M$, Johnson CA, Liu X. Trends in asthma prevalence, health care use, and mortality in the United States, 2001-2010. NCHS data brief, no 94 . Hyattsville, MD: National Center for Health Statistics.

34. Jayaram L, Pizzichini MM, Cook RJ, Boulet LP, Lemière $C$, Pizzichini E, Cartier A, Hussack P, Goldsmith $\mathrm{CH}$, Laviolette M, Parameswaran K, Hargreave FE. Determining asthma treatment by monitoring sputum cell counts: effect on exacerbations. Eur Respir J. 2006;27(3):483-94.

35. Dweik RA, Boggs PB, Erzurum SC, Irvin CG, Leigh MW, Lundberg JO, Olin AC, Plummer AL, Taylor DR. An Official ATS Clinical Practice Guideline: Interpretation of Exhaled Nitric Oxide Levels (FENO) for Clinical Applications. Am J Respir Crit Care Med. 2011;184(5):602-15.

- Manuscript received March 23, 2016; accepted for publication August 23, 2016.

\section{Ulla Seppälä}

\author{
Medical Affairs \\ Aerocrine AB \\ Råsundavägen 18 \\ P.O. Box 1024 \\ SE 17121 Solna, Sweden
}

